\title{
Reflections on the Loss of a Friend and Colleague: In memory of Assoc. Prof. İsmail Özbay MD, PhD
}

\author{
(D) Gönül KEMIKLER
}

Department of Medical Physics, İstanbul University Institute of Oncology, İstanbul-Turkey

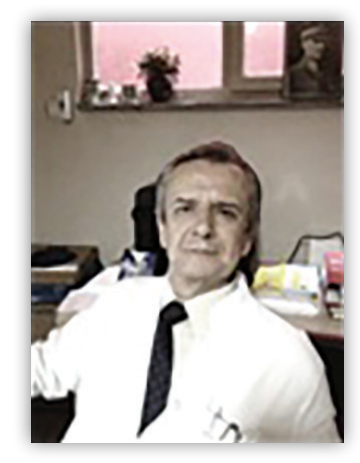

A friendship that began in the Faculty of Science at Istanbul University became a bond lasting 45 years, nearly a lifetime.

İsmail Özbay was born in 1951 in Karamürsel. He had a very happy childhood as a member of a large, crowded family living with his relatives. Ismail devoted himself to his extended family and his fellow man. After graduating from Gölcük High School in 1968, he eagerly began to study in the Physics Department of Istanbul University Faculty of Science. He was a smart and friendly young man, full of life, and fond of sports, and this would not change. After graduating from the faculty in 1974 as a physicist, we became colleagues in the Department of Radiotherapy of the Istanbul University Faculty of Medicine.

Ismail, Mrs. Alpar Dadaşbilge ( Ph.D.), Mr. Gökçen Kirtıoglu, and I worked together with our mentor, Assoc. Prof.Dr. Seyfettin Kuter, in the Department of Radiotherapy for several years. Unfortunately, none of them are with us today. From 1974 to 1978, Ismail studied the Cathetron high dose rate brachytherapy device, in collaboration with another mentor, Prof. Dr. $\mathrm{R}$. Uzel. Then, he closely analyzed the dose distribution of Curietron high and low dose rate devices and patient dosimetry. His interest in brachytherapy never diminished. A large part of our professional life was spent working in the application of manual brachytherapy, where Dr. Gökhan Töre, Dr. İsmail, Dr. Işık Aslay, and I, with nurses Mrs. Meryem Ardagil and Miss Bingül Kutlar, worked together as a happy and harmonious team. The calculations and analysis of orthogonal films of interstitial brachytherapy obtained using radium sources and subsequently iridium-192 wires that Ismail would pursue sometimes might last for days, but he performed these calculations without getting bored or tired. His dedication also showed in that he used to prepare the radioactive sources with great care and often by himself. It was another reflection of his calm, problem-solving nature.

Academic career opportunities in medical physics expanded after the establishment of the İstanbul University Institute of Oncology with the efforts of Prof. Dr. Nijad Bilge, Prof. Dr. Gökhan Töre, and Prof. Dr. Münir Kınay, and in 1986, Ismail began to work toward his master's degree.

In 1987, he attended a European Society for Radiotherapy and Oncology course on radiation physics for clinical radiotherapy in Leuven, Belgium. He then 
worked on routine clinical applications of the linear quadratic model and introduced it into clinical practice. He gave many seminars and lectures on this subject.

In 1988, he completed his master's degree of science at the Institute of Oncology with the postgraduate thesis "Computer-based calculations of dose distributions and risky organ doses in the treatment of uterine cancer with Curietron afterloading." In 1988 he also became a founding member of the Turkish Medical Physics Association. He was the general secretary of the association from 1988 until 2005.

We attended many professional conferences and training meetings together. In January 1990, along with Assoc. Prof. Dr. Seyfettin, we attended a Mevatron user meeting in Berlin and were there to witness the fall of the Berlin Wall. That same year, Ismail also joined the medical physicists at the Bodrum School of Physics, which he loved very much, to share his knowledge and experience with his colleagues.

In 1992, he completed his Ph.D. degree at the Institute of Oncology with his thesis "The intracavitary irradiation of cervix uteri cancer using modern afterloading techniques." In 1993, he became an assistant professor at the Istanbul University Institute of Oncology. In 1994, he participated in Turkey's first National Congress of Radiation Oncology.

At the many conventions we attended, most often related to brachytherapy, in addition to absorbing scientific knowledge, he always had a great desire to know the city we were visiting. He used to insist that the best way to know the city is to stroll through it, so of course, we did. Sometimes we used to walk until our feet were sore and swollen, but in one day we had a profile of the city. We used to attend meetings until 17.00, and then we would continue our sightseeing tours. He had an incredible memory and sense of direction. In a short time, without needing a map, he could master the city as if he had lived there be-

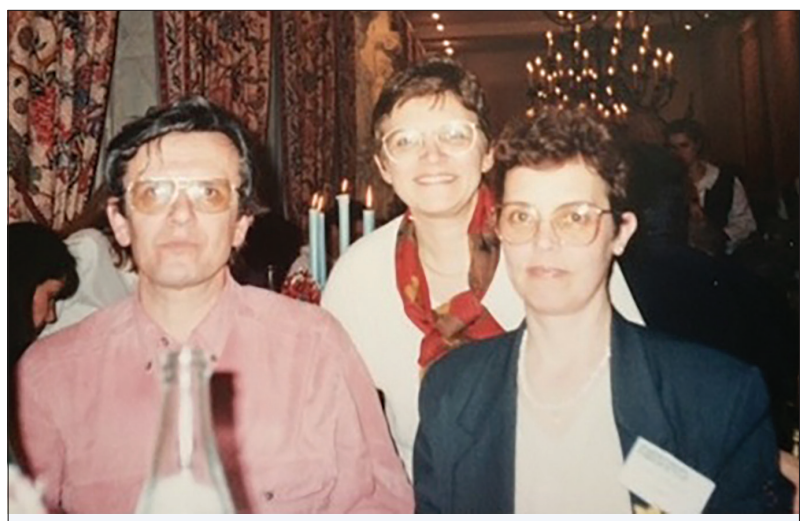

Fig. 1. A GEC-ESTRO annual meeting held in Naples, Italy. fore. Figure 1 is a memory of the GEC-ESTRO annual meeting held in Naples, Italy in 1998.

Ismail was a patient and humanitarian individual who never said or had an unkind thought about anyone. He had a humble and sincere character, and treated everyone equally. He was a person who knew how to genuinely share in our joys and listen to our sorrows, and he could be counted on to remain calm in the event of a problem. But he was stubborn. One of his defining characteristics was that he always objected to everything. He would make these objections without hesitation, and would express his every thought clearly.

Monday mornings were of special importance. Ismail was a great fan of the Fenerbahce football club. Even when the team was defeated, he would praise the team to the skies. If he was watching Galatasaray play Fenerbahçe with Dr. Nazmi, a Galatasaray fan, their loud voices could be heard from quite a distance, but eventually friendship would prevail.

We worked together throughout our academic life and prepared for our exams together. In 1998, he received his credentials as an associate professor from Istanbul University Faculty of Science Department of Radiobiology and General Biology. We achieved the title of associate professor with two days apart in October 1998. Hatice Bilge, Ismail, and I were very happy when we were photographed in those robes (Fig. 2).

In 1999, Ismail received training at the University of Leeds in England to initiate low dose rate prostate seed implantation at Istanbul University Institute of Oncology as part of the project "LDR iodine-125 seed implantation in prostate cancer treatment and establishment of HDR iridium-192 interstitial brachytherapy systems and dosimetry" managed by Prof. Dr. Iş1k Aslay. Prostate seed brachytherapy was then implemented for the first time in Turkey.

Ismail also had an active role in the research project "Introduction of dosimetry and application methods of

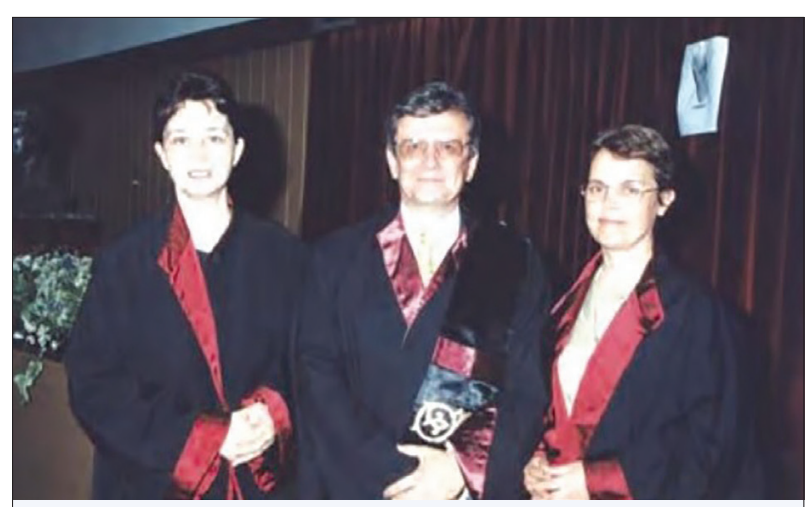

Fig. 2. At gowning ceremony after being an associate professor (1998). 
episcleral plaque implantation using iodine- 125 radioactive seeds in the treatment of choroid melanoma and retinoblastoma in clinical practice," managed by Prof. Dr. Gönül Peksayar, and he made immense contributions to the research.

He was head of the Department of Medical Radiophysics in Oncology Institute from 2001 to 2006. As he did throughout his career, he consistently displayed a democratic, principled, and unbiased perspective and stood behind his decisions for what he believed was right. He became an exemplary figure for everyone with his disciplined and patient personality. He was also very interested in his students and always encouraged them in their studies. Our country now has many medical physicists thanks to the courses he gave and master's and doctorate theses prepared under his guidance.

Ismail was the president of the Turkish Medical Physics Association from 2006 until 2013. He was part of the organizing committee of the 12th, 13th, and 14th National Congress of Medical Physics in 2009 through 2013.

Çetin Altan once had said: "Life is as much as it is lived. The rest is reminiscence in memory, or hope in dreams. I accept the frustration in one place. When I didn't live some moments when it was possible to live." I think my friend, Ismail, was able to accomplish most of what he wanted to while he was in good health. He loved to live life, to travel, to dress well, and to eat good food.

Life can prepare very bitter surprises for people. Ismail had 3 children. The death of his son at 26 years old almost destroyed him; it was almost as if it also took his life. He kept all his sorrow and pain to himself and did not like to share his troubles. In 2011, during the Institute's Brachytherapy Sharing Days practical applications, his blood pressure rose to $23 \mathrm{mmHg}$, and he had difficulty speaking. But as usual, he did not think much of his own health and said, "I am okay, please don't exaggerate my condition." It was only at great insistence that he began to take medication.

In 2014, 15 days after the Radiation Oncology Congress, he did not look very good during a brachytherapy planning session. But he didn't complain, and again said that he was OK. That was the last conversation we had while he was healthy. The next day, on the morning of May 8, 2014, he was urgently brought to the Emergency Department of the Istanbul University İstanbul Faculty of Medicine with an embolism in the brain stem. For the next 2 years, his life was so restricted that he could not do anything he liked, but he never once complained. Before each medical check-up, we waited with hope in our hearts for good news about his condition.

Ismail's family, including his daughter, Seda, and his nephew, Irfan, and his many friends never left him alone during his illness. On Friday, February 11, 2016, unfortunately, we lost him. I lost my friend of 45 years. Our community lost a gentleman, a great mentor, and a big brother. He will always live on with us in the beautiful things he left behind, including our many years of friendship, so full of sweet and emotional memories. 